\title{
The socio-economic impact timeline in Serbia for persistent organic pollutants (POPs)
}

\author{
Jelena Milic ${ }^{\mathrm{a}, *}$, Marijana Curcic ${ }^{\mathrm{b}}$, Zvonko Brnjas $^{\mathrm{c}}$, Hristina Carapina ${ }^{\mathrm{d}}$, Jasminka Randjelovic e \\ Katarina Krinulovic ${ }^{\mathrm{f}}$, Aleksandar Jovovic ${ }^{\mathrm{g}}$
}

a University of Belgrade, Institute of Chemistry, Technology and Metallurgy, 11000 Belgrade, Serbia

${ }^{\mathrm{b}}$ University of Belgrade, Faculty of Pharmacy, 11000 Belgrade, Serbia

c Institute for Economic Science, 11000 Belgrade, Serbia

d Faculty of Environmental Protection, University EDUCONS, 21208 Sremska Kamenica, Serbia

e Safer Chemicals Alternative-ALHem, Hektoroviceva1a, 11000 Belgrade, Serbia

${ }^{\mathrm{f}}$ ChemExpert, 11000 Belgrade, Serbia

${ }^{\mathrm{g}}$ University of Belgrade, Faculty of Mechanical Engeneering, 11000 Belgrade, Serbia

\section{H I G H L I G H T S}

- This study roughly quantifies the impact of POP chemicals on human health in Serbia.

- POPs chemicals have negative impact to economic development.

- Cost of diseases possibly caused by POPs in Serbia could reach €68 million in 5y time.

- According to BCR ratio, every $€ 1$ of cost will return $€ 2.77$ of benefit in $5 y$ time.

\section{A R T I C L E I N F O}

\section{Article history:}

Received 13 April 2019

Received in revised form 28 May 2019

Accepted 11 June 2019

Available online 12 June 2019

Editor: Adrian Covaci

\section{Keywords:}

Socio economic assessment

Persistent organic pollutants (POPs)

Environmental impact

Economic development impact

Human health impact
G R A P H I C A L A B S T R A C T

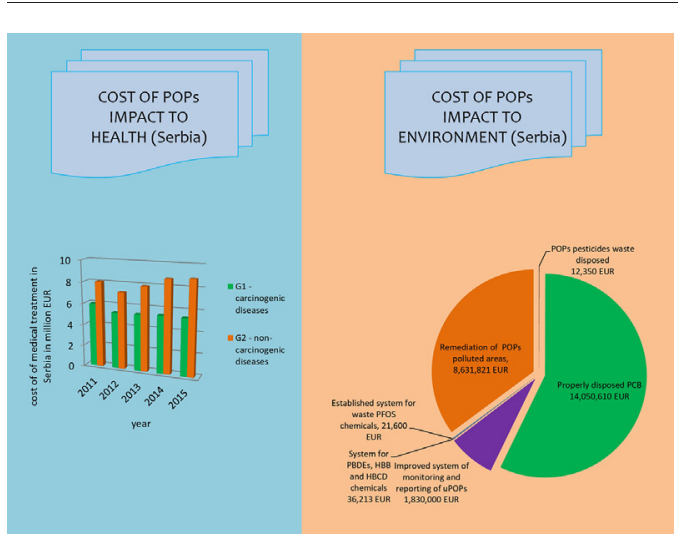

\section{A B S T R A C T}

Assessing the socio-economic impact of dangerous chemicals, including persistent organic pollutants (POPs) as a specific segment, includes analysis of their impacts on human health, on the environment and on local economic development. Abundant evidence of these effects of dangerous chemicals throughout the world is provided by published research. According to WHO, these chemicals cause around 4.9 million deaths (8.3\%) and 86 million Disability-Adjusted Life Years (5.7\%) globally; according to very conservative estimates, $20 \%$ of cancer deaths are the consequence of the cancerous effects of chemicals in the work place. Their impact on economic development is manifested primarily through reduced productivity of society due to health impairment of both the population and natural resources. Specific research, the results of which are presented in this article, has been focused on the impact of POPs on human health. This impact is presented in very general terms through estimation of the monetized cost effects for treating those diseases and cancers assumed to be caused by POPs in Serbia. The cost estimation based on available data amounts to approximately $€ 68$ million for a 5-year period.

(c) 2019 Elsevier B.V. All rights reserved.

\footnotetext{
* Corresponding author.

E-mail address: jelenamilic@chem.bg.ac.rs (J. Milic).
} 


\section{Introduction}

The Stockholm Convention on Persistent Organic Pollutants (POPs) aims to restrict and ultimately eliminate production, use, release and storage of POPs, and currently, the Convention lists 29 chemicals meeting the criteria for classification as POPs, which are: adverse effects to human health, persistence, bio-accumulation and potential for long-range environmental transport (Stockholm Convention, 2004). Consequently, POPs could have significant economic consequences, which will affect economic growth as well as welfare (Stockholm Convention, 2004).

The Republic of Serbia ratified the Stockholm Convention in 2009 and prepared a National Implementation Plan (NIP, 2010) and an Updated plan (UNIP, 2015). For the purpose of this study, we will give a brief description concerning the cost of POP-polluted environments and POP-related disease costs in Serbia, i.e. a socio-economic impact over a timeline of five years.

\subsection{POPs in Serbia}

According to UNIP, it is established there is no specific, deliberate production, import or export of POPs in Serbia, nor any use of EUbanned POP compounds in agriculture or industry (UNIP, 2015). However, the country held 1.35 tons of POP pesticides, identified in 2014 (Stevanovic-Carapina et al., 2016). Concerning POP industrial chemicals, the amounts were assessed for the following types: polychlorinated biphenyls (PCBs), polybrominated diphenyl ethers (PBDEs), hexabromocyclododecane (HBCDD) and perfluorooctanesulfonic acid (PFOS). Based on the results of a detailed inventory of PCB-containing transformers in Serbia, as well as on additional testing performed, it was estimated that approximately 7\% (around 4480) of transformers contain PCBs, as does 585 tons of oil from transformers (UNIDO, 2014). Furthermore, $5-8 \%$ of low voltage transformers (LVTs) in Serbia are contaminated with PCBs (i.e. around 4200 LVTs), because PCBs have remained as residues after cleaning and recharging transformers with mineral oil. The amount of contaminated oil from LVTs is assessed at 1200-1900 tons. Concerning waste, the quantity of generated PCB waste amounts to 112.2 tons, and the amount of PCB waste exported was 419 tons in total. The estimated amount of PBDEs in vehicles in Serbia was around 13 tons, while cathode ray tube casings in electrical and electronic equipment hold amounts ranging from 46.9 to 136.9 tons. The assessed overall quantity of HBCDD on the market in Serbia was 37.3 tons, although we emphasize this assessment is unreliable due to the unavailability of some relevant data. Concerning PFOS chemicals, the presence of fire fighting foams containing PFOS was identified in the past, but most of that foam was utilized during the NATO bombing campaign in 1999. Data on the import of Teflon and Teflonbased products that could contain PFOS suggest a need for increased inspection, supervision and laboratory analysis of the PFOS content in these products (Stevanovic-Carapina et al., 2016).

Based on the results of a preliminary inventory of unintentionally produced POPs, these chemicals are emitted to the environment from different sources located throughout Serbia. The most significant unintentional POP sources are: open burning processes; PCBs released from electrical equipment, and; production of electric and heating energy. Furthermore, in Serbia, there are over 3000 unsanitary landfills scattered around the country, and the significant portion of POP emissions reaching the environment from these existing dumpsites indicates inappropriate application of waste management systems (Stevanovic-Carapina et al., 2016).

\subsection{Contents and importance of the socio-economic impact assessment}

The socio-economic impact assessment (SEIA) of hazardous chemicals is defined as a systematic assessment of a potential impact of economic and other activities to all parts of society, including local communities and groups, the civil society, the private and public sectors, etc. (Eythorsson et al., 2015). The SEIA is a tool for analyzing and managing intended and unintended influences or effects (both positive and negative), interventions (policies, programs, plans and projects) and any other social change initiated by these interventions (Brnjas et al., 2015; Fischer et al., 2005).

The above-mentioned impacts of hazardous chemicals can be classified into three basic groups, as follows: impact on the health of people; impact on the environment, and; impact on economic development (Eythorsson et al., 2015). All these aspects have been the focus of specific research efforts, but the strongest emphasis is put on assessing the impact on human health, and particularly the impact in the work place. As well, numerous research activities have focused on the effects that chemicals have on the environment, while a somewhat lower number of research activities have dealt with their economic development impact (Eythorsson et al., 2015).

One of the most important efforts to quantify the adverse effects of chemicals on human health has been made by the World Health Organization (WHO) (Prüss-Ustün et al., 2011; WHO, 1994, 2010). The adverse impact of chemicals on human health was quantified with the help of two basic indicators: the number of deaths (per annum) and the number of Disability-Adjusted Life Years (DALY), i.e., the number of days lost to deteriorating health and illnesses. According to estimates presented in the WHO study (Prüss-Ustün et al., 2011) presented in the current study, in 2004, around 4.9 million deaths (8.3\% of the total deaths) and 86 million DALY (5.7\% of the total DALY) globally were the consequence of effects of the analyzed chemicals on the environment and humans. Additionally, the effects of chemicals in the work place, acute chemical poisoning and poisoning with pesticides have caused $375,000,240,000$ and 186,000 deaths, respectively. The magnitude and importance of these effects can be presented even more clearly by comparing them with other known causes of deaths which are recorded with relatively more reliable data. Therefore, in the observed year, 2.16 million people died of HIV/AIDS, 1.5 million of tuberculosis, 1.27 million from traffic accidents, 0.9 million of malaria, etc. (McKenna et al., 2005).

There have also been numerous attempts to monetize the adverse effects of hazardous chemicals, i.e., to present them in financial terms. These attempts are characterized by different approaches which reflect the different methodologies applied, different scope of research and choice of chemicals (individual or groups) which have been researched, and so their results are very difficult to compare.

Research activities of this type put special emphasis on determining the effects of chemicals in the work place. Thus, Pickvance et al. showed that if the application of measures specified by the framework of the EU REACH programme (Registration, Evaluation, Authorisation and Restriction of Chemicals - an EU regulation introduced in 2007) ceased to exist, in the period of the next 30 years, an additional $€ 90.9$ billion would be generated as costs (Pickvance et al., 2005). These include costs of medical treatments, effects of reduced productivity, and reduced quality of life due to chronic illnesses such as pulmonary diseases and dermatitis (Pickvance et al., 2005). On the other hand, increased costs to chemical and other affiliated industries resulting from the application of REACH measures have been estimated at $€ 2.8-5.2$ billion, for a period of 15 years.

The objective of the current study was to quantify the impact of POP chemicals on human health in Serbia, specifically on the carcinogenic and non-carcinogenic diseases and, where it was possible, to monetize these effects and express them in financial terms. This study also assessed the health and environmental cost benefits in the scenario of a 5-year phase out (disposal, decontamination and reduction) of POPs in the environment. To the best of our knowledge, this the first time such analysis has been conducted.

\section{Materials and methods}

Bearing in mind there are no specific data or research based on which registered cases of illness can be classified by cause, it is very 
difficult to provide stated costs which might be directly linked with POPs. In the present work, we give preliminary estimations of costs of medical treatments of diseases which can potentially be caused by POPs, under a three pillar approach:

- To analyze the health impact of POPs in Serbia. Given the limited resources (financial, human and time) available for research on this subject, the health impact assessment in Serbia in this study is somewhat limited to an attempt to estimate the cost of medical treatments of diseases which could potentially be caused by POPs. Special emphasis was put on the following diseases coded under the International Classification of Illnesses (WHO, 2016): Code cancer: C15 Malignant oesophageal tumor; Neoplasm malignum oesophagi; C16 Malignant stomach tumor; Neoplasm malignum gasteris; C17 Malignant small intestine tumor; Neoplasm malignum intestini tenuis; C18 Malignant appendiceal tumor; Neoplasm malignum caeci; C19 Malignant rectosigmoid colon junction tumor; Neoplasm malignum juncturae coli rectosigmoidis; C20 Malignant rectal tumor; Neoplasm malignum recti; C21 Malignant anal tumor, not specified; Neoplasm malignum ani, non specificatum; C22 Malignant liver and bile duct tumor; Neoplasma malignum hepatis et ductuum biliarium intrahepaticorum; C23 Malignant gallbladder tumor; Neoplasma malignum vesicae felleae; C24 External bile duct tumor; Neoplasma malignum ductus biliaris extrahepatici; C25 Malignant pancreas tumor; Neoplasma malignum pancreatis; C26 Malignant gastrointestinal tumor, not specified; Neoplasma malignum tractus intestinalis, non specificatum; C34 Malignant tracheal tumor; Neoplasma malignum bronchi principalis; C43 Lip melanoma; Melanoma malignum labii oris; C44 Other malignant skin tumors; Neoplasma malignum cutis alius; C46 Kaposi's sarcoma - malignant connective tissue tumor; Sarcoma Kaposi; C50 Malignant nipple and areola tumor; Neoplasma malignum papillae et areolae; C73 Malignant thyroid tumor; Neoplasma malignum glandulae thyreoideae; C81 Hodgkin's disease - Malignant lymphatic tissue tumor; Morbus Hodgkin; C82 Follicular Non-Hodgkin lymphoma of small cells with incised nuclei; Lymphoma non-Hodgkin folliculare cellularum parvarum cum nucleis incisis; C83 diffuse non-Hodgkin lymphoma of small cells; Lymphoma non-Hodgkin cellularum parvarum diffusum; C84 Mycosis fungoides; Mycosis fungoides (cancer codes), and K71 Liver disease caused by toxins; Morbus hepatis toxicus; K72 Liver insufficiency; Insufficientia hepatis; K73 Chronic liver inflammation; Hepatitis chronica; E03.2 Thyroid deficiency caused by the use of drugs and other substances; Hypothyroidisms medicamentosus et hypothyroidisms propter usum substantiarum exogenium aliarum; E03 Other types of thyroid deficiency; Hypothyroidisms alius; G11 Ataxia - hereditary movement disorder; Ataxia hereditaria; G40 Epilepsy; Epilepsia; G43 Migraine - one-sided headache attacks; Migraena; G44 Other headaches; Cephalalgiae aliae; G45 Temporary ischemia - insufficient blood flow to the brain and related syndromes; Ischaemia cerebri transitiva et syndromae affines; G46 Cerebrovascular disease; Sindromae vasculares cerebrales (I60-I67+); G47 Sleep disorder; Disordines somni; D80-D82 Immunodeficiency; N0-N19 Renal Insufficiency; P05P08 Diseases related to pregnancy duration and fetus growth (other effects codes).

- To analyze the environmental impact of POPs in Serbia, data from official government sources and scientific research was used, and to predict costs of disposal and decontamination of POPs for a 5year phase-out scenario, methodology from UNIP was used (UNIP, 2015). In brief, 1. Screening of localities of high risk; 2. Preliminary investigation for localities where data missing are identified; 3. Human health and environmental risk assessment procedure for sites where contamination is identified; 4 . For contaminated sited use of BAT/BEP for protection of further exposure of humans and environment (i.e. bioremediation) and; 5 .
Simultaneously with bioremediation provide monitoring in order to check proposed measures efficacy (UNIP, 2015).

- To assess the socio-economic impact of POPs in Serbia, we used two indicators: (1) medical costs calculated as a percentage of the country's GDP, and; (2) benefit:cost ratio (BCR) for a 5-year phase-out scenario. The percentage of medical costs as a share of the GDP represents the gross potential contribution of environmental POPs to loss of GDP due to health care costs. The BCR is the ratio of benefits versus costs which indicates the level of benefit that will be accrued for every $€ 1$ of cost (Shively, 2012). The BCR should be greater than 1.0 in order for the proposed measures to be economically acceptable and it is unacceptable environmentally that we do not clean up the POPs.

\section{Results and discussion}

\subsection{Health impact of POPs in Serbia}

POPs cause a variety of adverse health effects, including reproductive, developmental, endocrine, and carcinogenic effects (Carpenter, 2011; Mouly and Toms, 2016; Vested et al., 2014). The primary route of exposure for the human population is through contaminated food, but other routes include contaminated water, air, proximity to POP-contaminated sites, and dermal contact with everyday use products that contain POPs (mainly PFOS and PBDEs). Furthermore, it is proven that POPs can be transferred through the human placenta and breast milk to newborns (Fång et al., 2015; Mead, 2008).

The Serbian NIP for the Stockholm Convention states the daily average PCB intake of an adult weighing $70 \mathrm{~kg}$ equals $0.79 \mu \mathrm{g}$ (this is $1.1 \%$ of the acceptable daily intake), based on the concentrations of POP compounds in food, atmosphere and soil in Novi Sad city (NIP, 2010). Petrovic et al. (2008) assessed dioxin and PCB intake via food in the Serbian population and calculated an average intake of these chemicals as $3.14 \mathrm{pg}$ TEQ $/ \mathrm{kg} / \mathrm{day}$. This was more than the maximum intake recommended for the EU by the Scientific Council on Food, set at 2 pg TEQ/kg/ day, still lower than the maximum intake recommended by the WHO of $4 \mathrm{pg} \mathrm{TEQ} / \mathrm{kg} / \mathrm{day}$, but much higher than new setted tolerable weekly intake for dioxins and dioxin-like PCBs in food of $2 \mathrm{pg} \mathrm{TEQ} / \mathrm{kg}$, which is approximately $0.3 \mathrm{TEQ} / \mathrm{kg} / \mathrm{day}$. The new TWI is seven-times lower than the previous EU tolerable intake set by the European Commission's former Scientific Committee on Food in 2001 and the new TWI is protective against effects on semen quality (EFSA, 2018). However, the goal of the WHO is to achieve an intake of $1 \mathrm{pg} \mathrm{TEQ} / \mathrm{kg} / \mathrm{day}$, so in Serbia, the level of dioxins and PCBs ingested via food, even though a deterministic procedure was applied, indicates the need to raise awareness of these food contaminants (Petrovic et al., 2008; NIP, 2010). Škrbić (2008) measured the concentrations of six marker PCBs in 35 composite samples of crop products and by-products of the food processing industry and assessed the dietary intake of these chemicals by the adult Serbian population. The average daily intake of the marker PCBs was assessed to be $172.2 \mathrm{ng} /$ day using a mean weight of $60 \mathrm{~kg}$ for the general population in Serbia. Wheat-based products contributed largely ( $141.0 \mathrm{ng} /$ day) to the estimated value, due to fact that these products are notably consumed in Serbia, while the contributions of edible oil (19.8 ng/day) and sugar (11.4 ng/day) were not pronounced. Other important sources included meat products, fish, dairy products and eggs (Škrbić, 2008). Another study revealed the results of monitoring three groups of POPs - DDT, HCH and PCBs - in early human breast milk for 27 years (1982-2009), indicating that concentrations of DDT and $\mathrm{HCH}$ had decreasing trends from 1982 to 2009, with small rises in 1994 (Vukavić et al., 2013). Concentrations of PCBs in early human breast milk generally decreased from 1982 to 2009; decreases were smooth and steep until 1994, but two small peaks occurred in 2003 and 2009. Although the estimated daily intake of PCBs was far below the upper 
daily limit for milk products in Serbia, their increased levels in breast milk in 2003 and 2009 was a clear indication of environmental influx of these compounds after 1994 (Vukavić et al., 2013). A report on dioxin congener patterns for two samples of free-range chicken eggs from the municipality of Obrenovac, Serbia showed the specific prevalence of PCDD (polychlorinated dibenzodioxin) congeners over other congeners in the eggs (5.2 and $2.2 \mathrm{pg}$ TEQ/g of PCDD/dibenzofurans in fat). These results point to chemical contamination from the nearby thermal power plant being a potential source of the egg contamination Obrenovac being a potential source of the egg contamination (Petrlík, 2015).

Currently, Serbia does not have any official data or specific research based on which registered cases of human disease could be classified by cause. Therefore, it is very difficult to estimate the critical effects which could be attributed to human exposure to POPs. For the purpose of initial estimation, we have identified the potential effects of 24 POPs on people's health (Table 1 ) and highlighted those effects with the most detrimental consequences (ATSDR, 2018; RHIF, 2017). Beginning with identified or potential cancers and other diseases caused by POPs, we put special emphasis on diseases coded by the International Classification of Illnesses into two groups: cancer coded and other effects coded. A review of diseases and their corresponding codes is presented in Table 1.

Based upon official data from the Republic Health Insurance Fund (RHIF), the costs of medical treatment in Serbia for two groups of patients with diseases are shown. The G1 group (Table 2) consists of carcinogenic diseases and G2 group (Table 3) comprises noncarcinogenic diseases, but in both cases, the diseases could potentially be the consequence of exposure to POPs (RHIF, 2017). This analysis covers a 5-year period, as a set period for further socio-economic analysis.

The annual costs related to the treatment of G1 group diseases in Serbia in the observed period ranged between approximately $€ 156$ million to $€ 176$ million. The average costs of treating individual patients were relatively stable and oscillated up to $€ 1500$ (Table 2).

The annual costs for treatment of $\mathrm{G} 2$ group diseases in the 5 -year period were between approximately $€ 237$ million and $€ 260$ million. The average cost of treating individual patients with G2 group diseases was between $€ 835$ and $€ 1010$ per patient (Table 3 ).

As is the case with many environmental pollutants, it is extremely difficult to establish that illnesses or diseases are directly attributable to exposure to a specific POP or group of POPs. This difficulty is further underscored by the facts that (a) POPs rarely occur in the environment as a single compound, and (b) individual field studies are insufficient to provide compelling evidence of cause and effect in their own right. Because of that, these estimations should primarily be regarded as an illustration, and the uncertainties must be taken into account, like genetics, life style as well as demographic characteristics of Republic of Serbia. Namely, import and export trends were checked based on Serbian data, however before 2006, Serbia was part of three different Unions, with Motenegro, as United Republic of Yugoslavia and Socialistic Federative Republic of Yugoslavia, and this entire factor can influence results. The main purpose here is to provide a basic idea of the level of these costs rather than to precisely determine the costs of medical treatment of the illnesses.

WHO indicates that around $20 \%$ of carcinogenic diseases are caused by hazardous chemicals (WHO, 2002). If we begin with a hypothesis that adverse effects of POP compounds might comprise at least $10 \%$ of the adverse effects of hazardous chemicals (or that they cause approximately $2 \%$ of all cases of carcinogenic diseases), we could reach a rather approximate estimate of costs required for treatment of the aforementioned diseases caused by POPs in Serbia. The fact that the WHO research pertains to the causes of carcinogenic diseases which originate from the work place means that the results are likely underestimated, even though it might be expected that work place exposure is more intense than general environmental exposure (WHO, 2002).
According to this assumption, the costs of medical treatment of carcinogenic diseases which could be connected to POPs ranged from $€ 3.1$ to 3.5 million annually (Table 4).

As regards the non carcinogenic diseases, it is not possible to present any kind of quantitative estimate due to lack of data and research. Nevertheless, primarily for the sake of illustration and presenting a very general picture about possible monetized human health effects of POPs, if we begin from the same assumption that POP compounds contribute $2 \%$ of the total effects of hazardous chemicals in humans, we would get annual estimates of these costs ranging from $€ 4.7$ to 5.2 million (Table 4).

The medical treatment costs of G1 and G2 diseases that could be potentially caused by POPs are, in total, between $€ 7.3$ and 8.4 million annually ( $€ 40,131,300$ for the 5 -year period).

In Serbia, the RHIF covers approximately $70 \%$ of the population. Besides that, some drugs and medical treatments require co-payments even if the patient is covered by the RHIF. Therefore, realistic health expenditure covered by the RHIF is assessed as being only $59 \%$ of the total expenditure (Burki, 2018). Bearing this in mind, the total cost to Serbia of medical treatment for diseases which could be potentially caused by POPs could be around $€ 68,019,000$ for the 5-year period.

\subsection{Environmental impact of POPs in Serbia}

The examination of the quality of surface waters and groundwater in accordance with the Programme of Systematic Water Quality Control is carried out by the Serbian Environmental Protection Agency. Information received on the status of the waters is the basis for making decisions regarding water management. Continuous monitoring of water quality serves as a relevant source of professional information on the state of water resources as well as a basis for protection of waters from contamination and for determining optimal use of waters.

Regarding the POP content in river waters in Serbia in 2012, lindane was registered in 9 out of 54 sites. Concentrations of aldrin, chlordane ( $\alpha$ and $\gamma$ ), endrin, hexachlorobenzene (HCB) and PCBs were below the limit of quantification (LOQ). All maximum concentrations measured were below the defined maximum permissible concentrations (MPC) (SEPA, 2017a, 2017b).

Regarding POPs in river sediment in 2012, PCBs were registered in 8 of 47 sites in concentrations lower than targeted values (TV) as defined in the relevant Serbian regulation (SOG, 2012). The maximum concentration of HCB measured was close to the limit of quantification (LOQ), whereas the concentrations of all other substances were below their respective LOQs (Beškoski et al., 2013).

Besides monitoring POPs in surface waters in Serbia, in accordance with the monitoring program of the Environmental Protection Agency, the Institute of Public Health Belgrade in cooperation with the Secretariat for Environmental Protection conducted monitoring of surface waters in 28 measurement sites on the smaller watercourses and the Sava and Danube Rivers in the territory of Belgrade (IPHB, 2013). Regarding POP compounds, the concentrations of all substances in waters and sediments were below the LOQs, except for PCBs in sediment of the Veliki Lug River at the bridge on the road to Jagnjilo. At this location, the PCB level was significantly above MPC defined in the relevant Serbian regulation. This indicates there is a contaminated site in the wider area acting as a source of PCBs in the water.

After the military conflict in 1999 and chemical accidents in Kragujevac, Bor, Pancevo and Novi Sad, public attention has been particularly focused on pollution of the environment and possible consequences on the health of the workers and local population. In addition, there is still a relatively small quantity of data on contents of relevant contaminants in environmental samples. Turk et al. (2007) analyzed PCBs, HCHs, DDT and metabolites by active and passive air sampling from three localities in Kragujevac. The concentration of PCB congeners, combined $\alpha-, \beta$ - and $\gamma-\mathrm{HCH}$, and DDT in Kragujevac were: 
Table 1

Review of POP compounds and their effects on human health (ATSDR, 2018).

\begin{tabular}{|c|c|c|c|c|c|c|}
\hline No & POP compounds & $\begin{array}{l}\text { Type } \\
\text { of } \\
\text { POPs }\end{array}$ & Effects & Critical effects & $\begin{array}{l}\text { Code for } \\
\text { carcinoma }\end{array}$ & $\begin{array}{l}\text { Code for } \\
\text { other } \\
\text { effects }\end{array}$ \\
\hline \multicolumn{7}{|c|}{ Annex A (elimination) } \\
\hline 1 & Aldrin & $\mathrm{P}^{\mathrm{a}}$ & $\begin{array}{l}\text { Neurological disorders, carcinogenic, } \\
\text { reproductive, endocrine }\end{array}$ & $\begin{array}{l}\text { CNS excitation; transaminase; suspected human } \\
\text { carcinogen }\end{array}$ & & K71-K73 \\
\hline 2 & Dieldrin & $\mathrm{P}$ & $\begin{array}{l}\text { Neurological disorders, carcinogenic, } \\
\text { reproductive, endocrine }\end{array}$ & $\begin{array}{l}\text { CNS excitation; transaminase; suspected human } \\
\text { carcinogen }\end{array}$ & & G40-G47 \\
\hline 3 & $\begin{array}{l}\text { Hexabromobiphenyl } \\
\text { (HBB) }\end{array}$ & $\mathrm{IC}^{\mathrm{b}}$ & $\begin{array}{l}\text { Skin changes (chlorine, hyperpigmentation); } \\
\text { neurological effects (muscle weakness and } \\
\text { spasms); carcinogenic }\end{array}$ & $\begin{array}{l}\text { Thyroid gland, T4 decrease, suspected human } \\
\text { carcinogen (breast, digestive system and } \\
\text { lymphoma) }\end{array}$ & $\begin{array}{l}\mathrm{C} 50 \\
\mathrm{C} 15-\mathrm{C} 26 \\
\mathrm{C} 81-\mathrm{C} 84\end{array}$ & E03 \\
\hline 4 & $\begin{array}{l}\alpha \text {-Hexachlorocyclohexane } \\
(\mathrm{HCH})\end{array}$ & $\mathrm{P}$ & $\begin{array}{l}\text { Neurological disorders, carcinogenic, } \\
\text { reproductive, endocrine }\end{array}$ & $\begin{array}{l}\text { Hyperexcitability, epilepsy, convulsions, liver, } \\
\text { suspected human carcinogen }\end{array}$ & & K71-K73 \\
\hline 5 & $\begin{array}{l}\beta \text {-Hexachlorocyclohexane } \\
(\mathrm{HCH})\end{array}$ & $\mathrm{P}$ & $\begin{array}{l}\text { Neurological disorders, carcinogenic, } \\
\text { reproductive, endocrine }\end{array}$ & Hyperexcitability, epilepsy, convulsion and ataxia & & G11 \\
\hline 6 & Mirex & $\mathrm{P}$ & & Hepatotoxicity, suspected human carcinogen & & K71-K73 \\
\hline 7 & Endosulfan and isomers & $\mathrm{P}$ & & Neurological effects & & \\
\hline 8 & Chlordane & $\mathrm{P}$ & GIT diseases, neurological, liver, carcinogenic & Hepatotoxicity, suspected human carcinogen & & K71-K73 \\
\hline 9 & Endrin & $\mathrm{P}$ & CNS (Central Nervous System), etc. & CNS convulsions & & G40-G47 \\
\hline 10 & $\begin{array}{l}\text { Tetrabromodiphenyl ether } \\
\text { and pentabromodiphenyl } \\
\text { ether (penta-BDE) }\end{array}$ & IC & $\begin{array}{l}\text { Thyroid gland, neurological growth and } \\
\text { development, liver }\end{array}$ & $\begin{array}{l}\text { Neurobehavioral effects, thyroid hormones } \\
\text { homeostasis, suspected human carcinogen }\end{array}$ & & P05-P08, E03.2 \\
\hline 11 & $\begin{array}{l}\text { hexabromodiphenyl ether } \\
\text { and heptabromodiphenyl } \\
\text { ether (octa-BDE) }\end{array}$ & IC & $\begin{array}{l}\text { Neurotoxicity, liver, thyroid, growth and } \\
\text { development }\end{array}$ & $\begin{array}{l}\text { Hepatotoxicity (enzyme induction), suspected } \\
\text { human carcinogen }\end{array}$ & & K71-K73 \\
\hline 12 & Pentachlorobenzene & $\begin{array}{l}\mathrm{P} \\
\text { and } \\
\text { IC }\end{array}$ & & Hepatotoxicity, nephrotoxicity & & K71-K73 \\
\hline 13 & Chlordecone & $\mathrm{P}$ & & Renal effects, suspected human carcinogen & & N0-N19 \\
\hline 14 & Heptachlor & $\mathrm{P}$ & $\begin{array}{l}\text { Neurological, liver, reproductive, growth and } \\
\text { development }\end{array}$ & $\begin{array}{l}\text { Nervous and immune system development, } \\
\text { suspected human carcinogen }\end{array}$ & & D80-D82 \\
\hline 15 & Hexachlorobenzene (HCB) & $\begin{array}{l}\mathrm{P} \\
\text { and } \\
\text { IC }\end{array}$ & & $\begin{array}{l}\text { Hepatotoxicity, suspected human carcinogen } \\
\text { (thyroid, sarcomas) }\end{array}$ & $\mathrm{C} 73, \mathrm{C} 46$ & K71-K73 \\
\hline 16 & Lindane & $\mathrm{P}$ & & $\begin{array}{l}\text { Immunological effects and toxicity to } \\
\text { reproduction, growth and development }\end{array}$ & & P05-P08 \\
\hline 17 & $\mathrm{PCB}^{\mathrm{c}}$ & IC & $\begin{array}{l}\text { Skin changes (chlorine, hyperpigmentation); } \\
\text { neurological effects (muscle weakness and } \\
\text { spasm); carcinogenic }\end{array}$ & $\begin{array}{l}\text { Immunological effects, proneness to respiratory } \\
\text { system infections, suspected human carcinogen }\end{array}$ & & D80-D82 \\
\hline 18 & Toxaphene & $\mathrm{P}$ & & $\begin{array}{l}\text { Fatty liver disease, tubular necrosis, suspected } \\
\text { human carcinogen }\end{array}$ & & K73, N11 \\
\hline \multicolumn{7}{|c|}{ Annex B (restriction) } \\
\hline 19 & $\mathrm{DDT}^{\mathrm{d}}$ & $\mathrm{P}$ & $\begin{array}{l}\text { Nervous system (fatigue, convulsions), fertility, } \\
\text { pregnancy maintenance, lactation duration }\end{array}$ & Hepatotoxicity, suspected human carcinogen & & K71-K73 \\
\hline 20 & PFOS, PFOSA ${ }^{\mathrm{e}}$ & IC & & $\begin{array}{l}\text { Fetus development, reproductive system of the } \\
\text { fetus, neuroendocrine, suspected human } \\
\text { carcinogen (bladder cancer) }\end{array}$ & & P05-P08 \\
\hline \multicolumn{7}{|c|}{ Annex C (unintentionally produced, minimization, elimination) } \\
\hline 21 & $\operatorname{PCDD}^{f}$ & IC & $\begin{array}{l}\text { Chlorine, liver, thyroid, growth and development, } \\
\text { immune, reproductive, carcinogenic }\end{array}$ & $\begin{array}{l}\text { Toxicity to growth and development (especially } \\
\text { of reproductive system), suspected human } \\
\text { carcinogen (sarcomas, lymphomas, respiratory } \\
\text { system, gastrointestinal system) }\end{array}$ & $\begin{array}{l}\mathrm{C} 46 \\
\mathrm{C} 81-\mathrm{C} 84 \\
\mathrm{C} 34, \mathrm{C} 26\end{array}$ & P05-P08 \\
\hline 22 & $\mathrm{PCDF}^{\mathrm{g}}$ & IC & $\begin{array}{l}\text { Chlorine, liver, thyroid, growth and development, } \\
\text { immune, reproductive, carcinogenic }\end{array}$ & $\begin{array}{l}\text { liver (increased bilirubin, AST, ALT, TG), } \\
\text { suspected human carcinogen (skin and liver) }\end{array}$ & $\begin{array}{l}\mathrm{C} 43, \mathrm{C} 44 \\
\mathrm{C} 22\end{array}$ & K71-K73 \\
\hline 23 & HBB, PBDEs, HBCD & IC & $\begin{array}{l}\text { Liver, thyroid, growth and development, immune, } \\
\text { reproductive, carcinogenic }\end{array}$ & $\begin{array}{l}\text { HBB: liver, immune, DNA; probably carcinogenic } \\
\text { to humans }\end{array}$ & $\begin{array}{l}\text { C43, C44, } \\
\text { C22 }\end{array}$ & $\begin{array}{l}\text { K72, N0-N19, } \\
\text { E03, E08 }\end{array}$ \\
\hline 24 & PFOS & IC & $\begin{array}{l}\text { Immune, liver, and endocrine systems, } \\
\text { carcinogenic }\end{array}$ & $\begin{array}{l}\text { Immune, endocrine systems, possibly } \\
\text { carcinogenic to humans }\end{array}$ & $\mathrm{C} 22$ & K72,E03, E08 \\
\hline
\end{tabular}

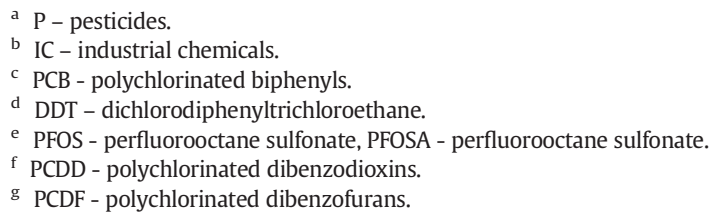

$\sum P C B=39.685 \mathrm{ng} / \mathrm{m}^{3}, \sum H C H=0.309 \mathrm{ng} / \mathrm{m}^{3}, \sum \mathrm{DDT}=0.321 \mathrm{ng} / \mathrm{m}^{3}$, respectively. The authors indicated that high levels of PCBs resulted from the destruction of transformers during an accident in the 1999 war (Turk et al., 2007).

As a part of the ICPDR Joint Danube Survey 2, a high PFOS concentration of $20 \mathrm{ng} / \mathrm{L}$ has been identified at the confluence of the Morava and
Danube Rivers (ICPDR, 2015). Relatively high concentrations of perfluorononanoic (PFNA), with an average value of $108 \mathrm{ng} / \mathrm{L}$, were detected in the Tisa River. In the same samples of the surface layers of the Tisa River, perfluoroundecanoic acid (PFUnA), perfluorooctanoic acid (PFOA) and PFOS were detected in maximum concentrations, i.e., above $10 \mathrm{ng} / \mathrm{L}, 3 \mathrm{ng} / \mathrm{L}$ and $3 \mathrm{ng} / \mathrm{L}$, respectively (Miloradov et al., 
Table 2

The cost to Serbia of medical treatment carcinoma that were potentially related to POP compounds from 2011 to 2015.

\begin{tabular}{llllll}
\hline Year & 2011 & 2012 & 2013 & 2014 & 2015 \\
\hline $\begin{array}{l}\text { Number of treated G1 }{ }^{\mathrm{a}} \text { patients } \\
\quad \text { without repetition }\end{array}$ & 118,720 & 114,678 & 109,644 & 126,337 & 125,908 \\
$\begin{array}{c}\text { Average cost }(€) \text { of G1 patient } \\
\text { treatment }\end{array}$ & 1482 & 1360 & 1431 & 1455 & 1492 \\
$\begin{array}{l}\text { Total cost of G1 treatment in } \\
\text { millions of } €\end{array}$ & 175.9 & 156.0 & 156.9 & 159.8 & 158.6 \\
\hline a G1 group consists of carcinogenic diseases. & & & & & \\
\hline
\end{tabular}

${ }^{a}$ G1 group consists of carcinogenic diseases.

2014). In addition, PFOS chemicals have been detected in high concentrations in the Danube watershed sediment downstream from the wastewater discharge location in the Pancevo industrial zone (there is an oil refinery and a petrochemical industrial complex here). Downstream from HIP Petrochemicals in the Pancevo petrochemical complex, 130, 170 and $5700 \mathrm{ng} / \mathrm{kg}$ of dry substance PFOA, PFHxA and PFOS, respectively, were detected, whereas downstream from the NIS Oil Refinery, also in Pancevo, 76, 66 and $420 \mathrm{ng} / \mathrm{kg}$ of dry substance of PFOA, PFHxA and PFOS, respectively, were detected (Beškoski et al., 2013).

In Serbia, 709 potentially contaminated and contaminated sites were identified and recorded in the government land registry, of which 557 sites are registered and 152 are presumed. Out of the 709 sites, 478 are still to be investigated and 103 are currently under investigation. Some sites (41) are in the process of rehabilitation, while rehabilitation and remediation (re-cultivation) are completed on 52 sites where after-care measures are currently being applied.

The highest number of registered sources of local soil contamination comes from municipal waste (43.5\%), followed by the exploitation and production of oil (31.7\%), locations for passengers and commercial transport (21.6\%), industrial waste (7.2\%) and from industrial and commercial activities (10.2\%) (SEPA, 2017a, 2017b).

This brief analysis of POPs in the environment in Serbia confirms the importance of adopting action plans for disposal and decontamination of POPs, thus preventing the further release of POPs into the compartments of the environment and food chain. One of the key methodological questions in the process of assessing costs of suitable action plans is how to, above all, as precisely as possible, determine these costs, and then to separate them from other costs of environmental protection. This is difficult because, very often, influences of POPs are manifested together with influences of other substances, and therefore, measures and instruments for their mitigation are applied simultaneously. For this reason, special attention was devoted to the separation of costs that are directly and exclusively related to POP compounds.

According to methodology given in UNIP (UNIP, 2015), the total cost of disposal of and decontamination from POPs chemicals in Serbia is calculated at $€ 24,582,000$ (scenario for 5-year phase out)

Table 3

The cost to Serbia of medical treatment for patients with diagnosed G2 (non-carcinoma) diseases.

\begin{tabular}{llllll}
\hline Year & 2011 & 2012 & 2013 & 2014 & 2015 \\
\hline $\begin{array}{c}\text { Number of treated G2a patients } \\
\text { without repetition }\end{array}$ & 234,943 & 237,931 & 256,399 & 353,066 & 347,482 \\
$\begin{array}{c}\text { Average cost }(€) \text { of G2 patient } \\
\text { treatment }\end{array}$ & 1010 & 894 & 909 & 835 & 886 \\
$\begin{array}{c}\text { Total cost of G2 treatment in } \\
\text { millions of } €\end{array}$ & 237.3 & 212.6 & 233.0 & 256.4 & 260.1 \\
\hline
\end{tabular}

\footnotetext{
a G2 group consists of non-carcinogenic diseases.
}

Table 4

Estimated costs to Serbia of medical treatment for diseases caused by POP compounds, in $000 \mathrm{~s}$ of $€$.

\begin{tabular}{lllllll}
\hline Group & Year & 2011 & 2012 & 2013 & 2014 & 2015 \\
\hline G1 $^{\text {a }}$ & Total cost of G1 treatment & 3518.9 & 3119.7 & 3137.9 & 3196.0 & 3172.5 \\
G2 $^{\text {b }}$ & Total cost of G2 treatment & 4745.7 & 4252.3 & 4659.8 & 5127.3 & 5201.4 \\
& TOTAL & 8264.6 & 7372.0 & 7797.6 & 8323.2 & 8373.9
\end{tabular}

a G1 group consists of carcinogenic diseases.

b G2 group consists of non-carcinogenic diseases.

and includes: properly disposed an existing quantities of POPs pesticides waste, decontamination of PCB containing equipment with the volume larger than $5 \mathrm{dm} 3$ and with $\mathrm{PCB}$ concentration above $50 \mathrm{ppm}$, improving system of monitoring and reporting and releases of unintentionally produced POPs chemicals into environment, establishing system for safe storage and treatment of chemicals, semi-finished products and products containing PBDEs, HBB and $\mathrm{HBCD}$ chemicals and waste containing these chemicals and reducing environmental pollution through remediation of identified POPs polluted areas (Fig. 1).

Finally, it is important to remember that all of the mentioned financial projections are rough estimations, being only a preliminary assessment that should be additionally specified (UNIP, 2015).

\subsection{Socio-economic impact of POPs in Serbia}

The indicators of the impact POP chemicals have on economic activities are shown in this study as a relative share of gross domestic product (GDP). In that sense, costs of medical treatments as a possible consequence of pollution are expressed as percentages of GDP which has been spent or lost (Table 5) (FREN, 2017).

It is important to note that the adverse human health effects are manifested further in the economic sphere of society mainly through: loss of family income due to death of a family member; reduction of income due to reduced working ability caused by disease and/or increased medical costs, and; increased cost of public health. Besides that, adverse effects on the environment include loss of biodiversity, decreased agricultural production levels and decreased food production (an important sector in the Serbian economy).

Using calculated costs in previous sector/chapters, it is possible to calculate the benefit:cost ratio (BCR) of phasing out and mitigating $\mathrm{POP}$ compounds in the environment over a 5 -year period:

$\mathrm{BCR}=$ value of benefits/value of costs $=2.77$

value of benefits: cost of G1 (G1 group consists of carcinogenic diseases) and G2 (G2 group consists of non-carcinogenic diseases) medical treatment for five years ( $€ 68,019,152$ ) value of costs: cost of disposal and decontamination scenario for 5-year phase out ( $€ 24,582,000)$.

Since it is likely the Serbian population will become further educated about the importance of a reduce, reuse and recycle ethos and the effectiveness of a circular economy, as experts from this field have proved (Robertson et al., 2018), the potential BCR should be assumed as being greater than this calculated value.

\section{Conclusions}

In conclusion, we have emphasized monetization of cost of diseases possibly caused by a specific group of hazardous chemicals, POPs, as inventoried in Serbia from 2011 to 2015. According to this BCR, every $€ 1$ of cost will return $€ 2.77$ of benefit after a 5-year period. We stress this is without the uncertainty of environmental benefits being monetized due to data gaps and the complexity of environmental services. The process of socio-economic analysis of 


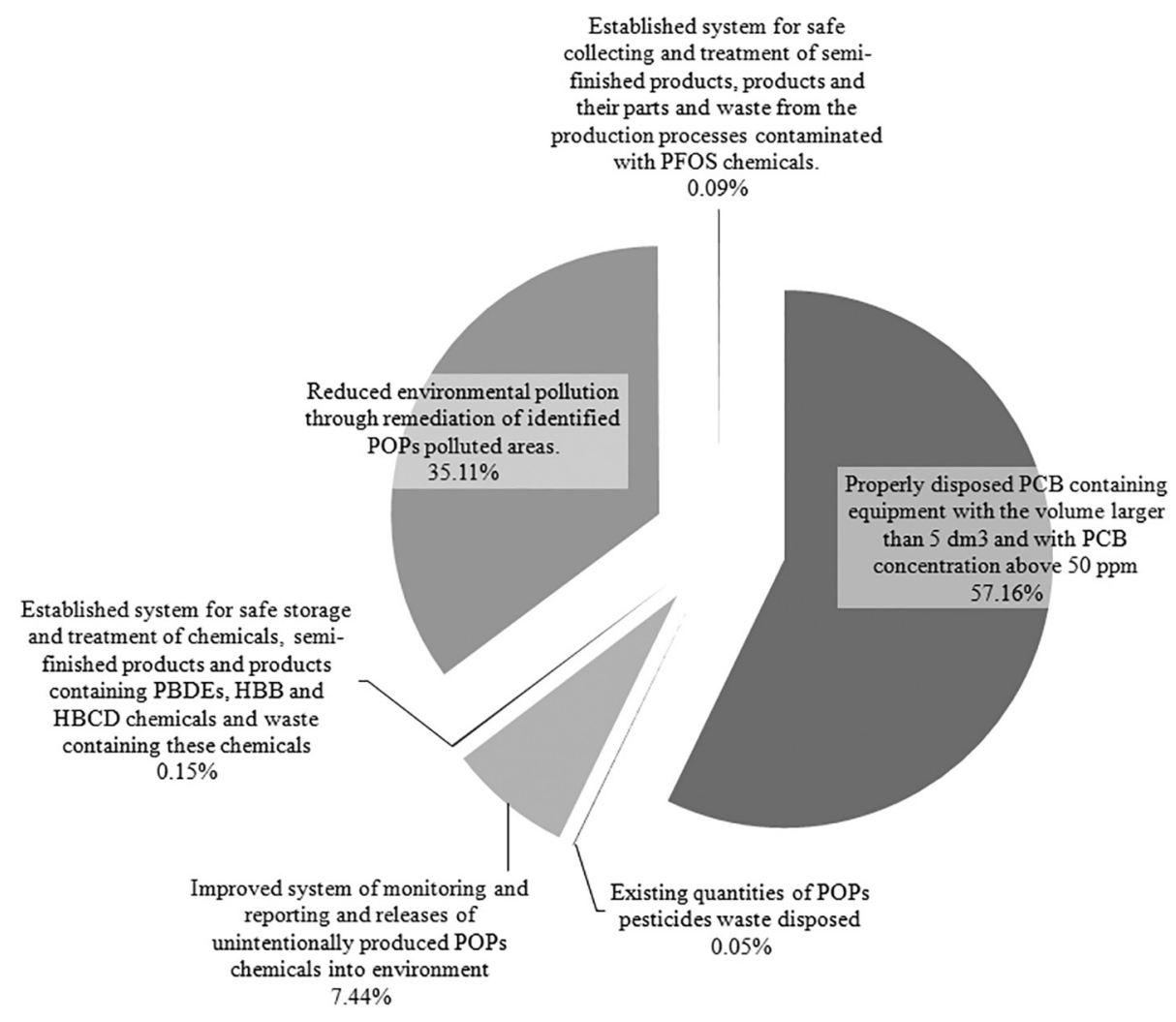

Fig. 1. Cost projections for disposal of and decontamination environment from POPs chemicals in Serbia.

hazardous chemicals impacts includes identifying anthropogenic activities which include dangerous chemicals; analyzing their adverse effects on the environment, and; assessing their impacts. Methods and indicators for measuring these impacts, and when possible monetizing them, contain some uncertainties. Therefore, these data should be used as an illustration of this comprehensive issue, and to underpin further, more precise calculations for national, health and environmental benefits.

\section{Acknowledgments}

The authors would like to acknowledge the following Projects: Programme in Higher Education, Research and Development (HERD) - Energy sector no. 05/14 funded by International Relations Office of the Ministry Foreign Affairs of the Kingdom of Norway, and Project III43004, funded by Serbian Ministry of Education, Science and Technological Development.

Table 5

Medical treatment costs as percentage of Serbian GDP.

\begin{tabular}{cccccc}
\hline Year & $\begin{array}{l}\text { Serbian GDP in } \\
\text { billions of } \\
\text { RSD }^{\text {a }}\end{array}$ & $€ /$ RSD & $\begin{array}{l}\text { GDP in } \\
\text { billions } \\
\text { of } €\end{array}$ & $\begin{array}{l}\text { Medical } \\
\text { treatment } \\
\text { costs } €)\end{array}$ & $\begin{array}{l}\text { Percentage of } \\
\text { treatment costs } \\
\text { as } \\
\text { share of GDP }\end{array}$ \\
\hline 2011 & 3407.6 & 102.0 & 33.42 & $175,900,000$ & $0.53 \%$ \\
2012 & 3584.2 & 113.1 & 31.68 & $156,000,000$ & $0.49 \%$ \\
2013 & 3876.4 & 113.1 & 34.26 & $156,900,000$ & $0.46 \%$ \\
2014 & 3908.5 & 117.3 & 33.32 & $159,800,000$ & $0.48 \%$ \\
2015 & 4043.0 & 120.7 & 33.49 & $158,600,000$ & $0.47 \%$ \\
\hline
\end{tabular}

a RSD; Republic of Serbia dinar. Average exchange rate of RSD vs. €; official data of National Bank of Serbia.

\section{References}

Agency for Toxic Substances and Disease Registry (ATSDR) (2018) Toxicological Profiles (Tox Profiles). https://www.atsdr.cdc.gov/toxprofiles/index.asp

Beškoski, V.P., Takemine, S., Nakano, T., Beškoski, L.S., Gojgić-Cvijović, G., Ilić, M., Miletić, S., Vrvić, M.M., 2013. Perfluorinated compounds in sediment samples from the wastewater canal of Pančevo (Serbia) industrial area. Chemosphere 91, 1408-1415. https://doi.org/10.1016/j.chemosphere.2012.12.079.

Brnjas, Z., Ćurčić, M., Dedeić, P., 2015. Socio-economic aspect of hazardous chemicals environmental impacts. Info M: časopis za informacionu tehnologiju i multimedijalne sisteme. 156-164 (in Serbian).

Burki, T.K., 2018. The long road to recovery from conflict in Serbia. Lancet 6, 413-414. https://doi.org/10.1016/S2213-2600(18)30205-4

Carpenter, D.O., 2011. Health effects of persistent organic pollutants: the challenge for the Pacific basin and for the world. Rev. Environ. Health 26, 61-69. https://doi.org/ 10.1515/reveh.2011.009.

European Food Safety Authority (EFSA), 2018. Dioxins and related PCBs: tolerable intake level updated. https://www.efsa.europa.eu/en/press/news/181120.

Eythorsson, G.T., Johannesson, H., Olafsson, K., 2015. Socio-economic impact assessment Planning for Sustainable Development-the practice and potential of Environmental Assessment 6, 53-75.

Fång, J., Nyberg, E., Winnberg, U., Bignert, A., Bergman, Å., 2015. Spatial and temporal trends of the Stockholm convention POPs in mothers' milk - a global review. Environ. Sci. Pollut. Res. 22, 8989-9041. https://doi.org/10.1007/s11356-015-4080-z.

Fischer, G., Shah, M., Tubiello, F.N., Van Velhuizen, H., 2005. Socio-economic and climate change impacts on agriculture: an integrated assessment, 1990-2080. Philos T Roy Soc B 360, 2067-2083. https://doi.org/10.1098/rstb.2005.1744.

Foundation for the Advancement of Economics (FREN), 2017. Serbia: Quarterly Monitor of Economic Trends and Policies in Serbia, Selected Macroeconomic Indicators, 2006-2017 Belgrade, Serbia.

Institute of Public Health Belgrade (IPHB), 2013. Quality of Superficial Water on the Territory of Belgrade in 2012.

International Commission for the Protection of the Danube River (ICPDR) (2015) Joint Danube Survey Project 2. Final Scientific Report p.170 http://www.icpdr.org/jds/ files/ICPDR_Technical_Report_for_web_low_corrected.pdf

McKenna, M.T., Michaud, C.M., Murray, C.J., Marks, J.S., 2005. Assessing the burden of disease in the United States using disability-adjusted life years. Am J of Prev Med 28, 415-423. https://doi.org/10.1016/j.amepre.2005.02.009.

Mead, M.N., 2008. Contaminants in human milk: weighing the risks against the benefits of breastfeeding. Environ Health Persp 116, A426.

Miloradov, M.B., Turk Sekulic, M.M., Radonjić, J.R., Milić, N.B, Grujić Letić, N.N., Mihajlović, I.j., 2014. Industrial emerging chemicals in the environment. Hem. ind. 68, 51-62. https://doi.org/10.2298/HEMIND121110028V. 
Mouly, T.A., Toms, L.M., 2016. Breast cancer and persistent organic pollutants (excluding DDT): a systematic literature review. Environ Sci Pollut R 23, 22385-22407. https:// doi.org/10.1007/s11356-016-7577-1.

National Implementation Plan (NIP), 2010. NIP under the Stockholm Convention on POPs for Serbia. Ministry of Environmental Protection, Serbia in Accordance with Law on Ratification of the Stockholm Convention. Official Gazette of the RS - International Agreements No. 42/2009.

Petrlík J (2015) Persistent Organic Pollutants in Free Range Chicken Egos from Western Balkan Countries Bosnia and Herzegovina, Montenegro and Serbia 2014-2015. Arnika - Toxics and Waste Programme, Prague Peter Behnisch, Bio Detection Systems, Amsterdam Prague, vol. 2015 ISBN: 978-80-87651-17-9.

Petrovic, V., Curcic, M., Jankovic, S., Antonijevic, B., 2008. Average intake of dioxins and polychlorinated biphenyls among adult population in Serbia. 7th Xenobiotic Metabolism and Toxicity Workshop of Balkan Countries, Novi Sad, Serbia. Eur J Drug Metabol Pharmacokinet 33, 14.

Pickvance, S., Karnon, J., Peters, J., El-Arifi, K., 2005. The Impact of REACH on Occupational Health with a Focus on Skin and Respiratory Diseases. Final Report, September 2005. prepared for the. European Trade Union Institute for Research, European Trade Union Technical Bureau for Health \& Safety http://hesa.etui-rehs.org/uk/newsevents/files/ reach-sheffield-complet.pdf.

Prüss-Ustün, A., Vickers, C., Haefliger, P., Bertollini, R., 2011. Knowns and unknowns on burden of disease due to chemicals: a systematic review. Environ. Health 10 (1), 9. https://doi.org/10.1186/1476-069X-10-9.

Republic Health Insurance Fund (RHIF), 2017. Official Data of the RHIF on Funding Healthcare from 2011 to 2015. Ministry of Health Republic of Serbia.

Robertson, L.W., Weber, R., Nakano, T., Johansson, N., 2018. PCBs risk evaluation, environmental protection, and management: 50-year research and counting for elimination by 2028. Environ Sci Pollut R 25, 16269-16276. https://doi.org/10.1007/s11356-0182467-3.

Serbia Official Gazette (SOG), 2012. Regulation on limit values of pollutants in the surface waters, groundwater and the sediment and the deadlines for their achievement. Official Gazette RS No 2012 (In Serbian), 50.

Serbian Environmental Protection Agency (SEPA), 2017a. Quality of Water-Report. http:// www.sepa.gov.rs/download/KvalitetVoda2015.pdf.

Serbian Environmental Protection Agency (SEPA), 2017b. Investigation of potentially contaminated industrial sites in the republic of Serbia. http://www.sepa.gov.rs/download/prezentacije/2017/ICCL_2017_DVidojevic_ASiljicTomic.pdf.

Shively, Gerald, 2012. An Overview of Benefit-Cost Analysis. https://www.researchgate. net/publication/255661807_An_Overview_of_Benefit-Cost_Analysis.
Škrbić, B., 2008. Assessment of the Serbian population exposure to polychlorinated biphenyls by crops. Environ Toxicol Phar 25, 171-175. https://doi.org/10.1016/j. etap.2007.10.005.

Stevanovic-Carapina, H., Milic, J., Curcic, M., Randjelovic, J., Krinulovic, K., Jovovic, A., Brnjas, Z., 2016. Solid waste containing persistent organic pollutants in Serbia: from precautionary measures to the final treatment (case study). Waste Manage Res 34, 677-685. https://doi.org/10.1177/0734242X16650515.

Stockholm Convention on Persistent Organic Pollutants (POPs), 2004. http://chm.pops. int/TheConvention/Overview/tabid/3351/Default.aspx.

Turk, M., Jakšić, J., Miloradov, M.V., Klanova, J., 2007. Post-war levels of persistent organic pollutants (POPs) in air from Serbia determined by active and passive sampling methods. Environ. Chem. Lett. 5, 109-113. https://doi.org/10.1007/s10311-0060091-9.

United Nations Industrial Development Organisation (UNIDO), 2014. Pravilno upravljanje i finalno odlaganje PCB-a u Republici Srbiji (in Serbian), Twinning Project IPA 2013 Programme for Serbia. http://www.hazardouswaste-serbia.info/fileadmin/inhalte/ haz_waste/pdf/3_workshop_POPs_and_PCB/03_prof_Orlovic_SRB.pdf.

Updated National Implementation Plan (UNIP), 2015. UNIP under the Stockholm convention on POPs for Serbia (2015) Ministry of Environmental Protection, Serbia in accordance with law on ratification of the Stockholm convention. Official Gazette of the RS - International Agreements No. 42/2009.

Vested, A., Giwercman, A., Bonde, J.P., Toft, G., 2014. Persistent organic pollutants and male reproductive health. Asian J Androl 16 (1), 71. https://doi.org/10.4103/1008$682 X .122345$

Vukavić, T., Miloradov, M.V., Mihajlović, I., Ristivojević, A., 2013. Human milk POPs and neonatal risk trend from 1982 to 2009 in the same geographic region in Serbia. Environ. Int. 54, 45-49. https://doi.org/10.1016/j.envint.2013.01.008.

World Health Organization (WHO), 1994. Assessing human health risks of chemicals: derivation of guidance values for health-based exposure limits 170, 43-62. http:// apps.who.int/iris/handle/10665/40675.

World Health Organization (WHO), 2002. The world health report 2002: reducing risks, promoting healthy life. http://www.who.int/whr/2002/en/whr02_en.pdf?ua=1.

World Health Organization (WHO), 2010. Persistent organic pollutants: impact on child health, 9-44. http://www.who.int/ceh/publications/persistent_organic_pollutant/ en/.

World Health Organization (WHO), 2016. ICD-10: International Statistical Classification of Diseases and Related Health Problems: 10th Revision. World Health Organization https://icd.who.int/browse10/2016/en. 